\title{
Modyfikacja spoiwa wapiennego gipsem oraz metakaolinitem
}

\author{
Przemysław Brzyski, Katarzyna Świderczuk \\ Katedra Budownictwa Ogólnego, Wydział Budownictwa i Architektury, Politechnika Lubelska, \\ e-mail:p.brzyski@pollub.pl,katarzyna.swiderczuk@wp.pl
}

Streszczenie: Wapno od tysięcy lat wykorzystywane jest jako materiał budowlany. W dzisiejszych czasach, z uwagi na jego niską wytrzymałość mechaniczną i małą odporność na warunki atmosferyczne zmniejszono lub nawet zaniechano jego wykorzystanie w budownictwie. Ten naturalny budulec korzystnie wpływa na mikroklimat wewnątrz budynków, a dzięki zasadowemu odczynowi zapobiega powstawaniu pleśni. Stosowanie wapna jako zamiennika tradycyjnych materiałów, do których można zaliczyć np. cement przyniesie korzyści nie tylko ekologiczne ale i ekonomiczne.

W pracy opisano badania własne podstawowych właściwości fizyko-mechanicznych modyfikowanych spoiw wapiennych. W celu podwyższenia niekorzystnych parametrów wapna, zmodyfikowano spoiwo zmienną ilością gipsu w ilościach $10 \%, 15 \%, 20 \%$ masy spoiwa oraz różną zawartością wody poprzez wskaźnik woda/spoiwo W/S: $0,65,0,7,0,75$ dla mieszanki z $15 \%$ zawartością gipsu. W wszystkich recepturach zastosowano stałą ilość metakaolinitu równą $10 \%$ masy spoiwa. Przeprowadzono test wytrzymałości na zginanie i ściskanie po 7 dniach oraz badania gęstości, porowatości i nasiąkliwości spoiw. Przy wzroście zawartości gipsu odnotowano wzrost parametrów wytrzymałościowych i spadek nasiąkliwości przy niewielkich zmianach porowatości. Dużo większe różnice zaobserwowano przy modyfikacji W/S: wraz z jego spadkiem wzrastała wytrzymałość spadała nasiąkliwość i porowatość.

Słowa kluczowe: wapno, gips, metakaolinit, wytrzymałość, nasiąkliwość, gęstość, porowatość.

\section{Wstęp}

W obecnych czasach przemysł budowlany, nie tylko specjalny, ale również mieszkaniowy, małogabarytowy zdominowany jest przez materiały wytwarzane sztucznie. Najpopularniejszym z nich jest cement portlandzki, wykorzystywany niemal na każdej budowie, bez którego w opinii wielu inżynierów niemożliwe jest stworzenie wytrzymałej konstrukcji. Nie dawniej niż sto lat temu, gdy stosowanie tego materiału wiążącego nie było tak spopularyzowane, ludzie wykorzystywali między innymi surowce naturalne jak wapno czy glina do budowy trwałych budynków, a wiele $\mathrm{z}$ nich jak choćby te drewniane, wybudowane kilka wieków temu stoją do dnia dzisiejszego.

Zarówno spoiwa wapienne jak i gipsowe są jednymi z najstarszych materiałów wiążących, towarzyszących człowiekowi od tysięcy lat. Jak podaje [1] i [2], już starożytni Rzymianie wykorzystywali modyfikowane (np. naturalnymi pucolanami - popiołami wulkanicznymi) mieszanki wapienne jako spoiwo w swoich słynnych budowlach (np. Koloseum, akwedukty) oraz produkowali z nich zaprawy. W sytuacji gdy budownictwo zrównoważone i ekologiczne staje się coraz bardziej popularne nie tylko przy projektowaniu domów 
jednorodzinnych ale nawet w nowoczesnych rozwiązaniach technologicznych spoiwa naturalne stają się coraz bardziej pożądanym materiałem.

Dotychczasowe zastosowanie wspomnianych materiałów naturalnych było szeroko wykorzystywane w technikach renowacyjnych i dekoracyjnych budynków zabytkowych. W pracach tych skupiano się zazwyczaj na odtworzeniu historycznych składów mieszanek, na których powinny się wzorować współczesne badania i analizy spoiw wapienno gipsowych dążące do uzyskanie jak najlepszych efektów wytrzymałościowych i fizykochemicznych co widać w pracach [3] i [4].

Zaletą wapna hydratyzowanego jako spoiwa są jego właściwości wpływające korzystnie na mikroklimat wewnątrz budynków, który w dużym stopniu oddziałuje na organizm ludzki. Tynki wapienne wykazują zdolności regulowania poziomu wilgotności w pomieszczeniach. Wysoka paroprzepuszczalność tynków oraz zasadowy odczyn wapna czyni ten materiał wolnym od ryzyka rozwoju pleśni. Wapno znajduje zastosowanie w ochronie środowiska, np. w oczyszczaniu spalin ze spalania węgla, w instalacjach odsiarczających i przy usuwaniu metali ciężkich. Stosowane jest przy uzdatnianiu wody oraz przy oczyszczaniu ścieków. Wapno jest bardziej odporne na zarysowania pod wpływem odkształceń konstrukcji w porównaniu ze spoiwem cementowym.

Kamień gipsowy, z którego wykonuje się gips półwodny, podobnie jak wapno nie zawiera szkodliwych związków chemicznych, a jego niska temperatura prażenia czyni z niego materiał o aspektach ekologicznych. Spoiwa gipsowe, dzięki korzystnym właściwościom tego surowca można stosować do wykonywania tynków hipoalergicznych. Spoiwo to nie wydziela zapachu ani szkodliwych człowiekowi substancji. Ponadto powierzchnie gipsowe nie przyciągają kurzu gdyż nie gromadzą się na niej ładunki elektrostatyczne.

Stosowanie wapna oraz gipsu - naturalnych materiałów budowlanych, może z powodzeniem zastąpić w wielu przypadkach cement, zwłaszcza jeśli zostanie zmodyfikowane konkretnymi dodatkami polepszającymi jego niekorzystne właściwości fizyczne i wytrzymałościowe. Wykorzystanie naturalnych materiałów konstrukcyjnych jako substytutu dotychczas stosowanych produktów tradycyjnych niesie ze sobą wiele korzyści zarówno ekologicznych jak i ekonomicznych.

Celem pracy było określenie wpływu modyfikacji spoiwa wapiennego zawierającego stałą ilość metakaolinitu, zmienną ilością gipsu. Przeprowadzono podstawowe badania wytrzymałościowe (wytrzymałość na zginanie oraz ściskanie po 7 dniach) oraz zbadano właściwości fizyczne takie jak gęstość, porowatość oraz nasiąkliwość spoiw.

\section{Metody badań i wykorzystane materiały}

\subsection{Materiały}

Wapno hydratyzowane jest spoiwem powietrznym o niskich parametrach mechanicznych. Podwyższenie wytrzymałości realizowane może być poprzez modyfikacje np. dodatkami pucolanowymi, takimi jak zeolit, mikrokrzemionka, metakaolinit wg [5,6,7]. Dodatki pucolanowe wchodząc, w obecności wilgoci, w reakcję chemiczną z wodorotlenkiem wapnia powodują utworzenie związków o właściwościach hydraulicznych - uwodniony krzemian wapnia lub glinokrzemian wapnia. Pucolany poprawiają ponadto właściwości użytkowe spoiwa takie jak urabialność i konsystencja.

W pracy zastosowano wapno hydratyzowane CL90 - o minimalnej zawartości $\mathrm{Ca}(\mathrm{OH})_{2} 90 \%$, charakteryzujące się powierzchnią właściwą ok. $15000 \mathrm{~cm}^{2} / \mathrm{g}$. Wraz z powierzchnią właściwą rośnie strefa kontaktu co implikuje szybszy proces karbonatyzacji. Fakt ten narzuca konieczność przechowywania wapna w sposób nienarażający go na działa- 
nia powietrza i wilgoci, gdyż inaczej utraci swoje właściwości wiążące. Wapno hydratyzowane w obecności wilgoci oraz dwutlenku węgla $\mathrm{z}$ atmosfery wiąże i twardnieje w długotrwałym procesie karbonatyzacji, opisanym równaniem reakcji (1).

$$
\mathrm{Ca}(\mathrm{OH})_{2}+\mathrm{CO}_{2} \rightarrow \mathrm{CaCO}_{3}+\mathrm{H}_{2} \mathrm{O}
$$

Podczas badań wykorzystano metakaolinit jako częściowy zamiennik wapna, w ilości $10 \%$. Jest to wysoce reaktywny materiał pucolanowy, powstający poprzez prażenie kaolinu gliniastego w temperaturze $600^{\circ} \mathrm{C}-850^{\circ} \mathrm{C}$. W jego składzie dominuje uwodniony dikrzemian glinu $\mathrm{Al}_{2} \mathrm{Si}_{2} \mathrm{O}_{5}(\mathrm{OH})_{4}$. Dodatek metakaolinitu ma na celu polepszenie właściwości wytrzymałościowych wapna. Reaguje on z wodorotlenkiem wapnia obecnym w spoiwie wapiennym według reakcji (2) i (3).

$$
\begin{aligned}
& \mathrm{CH}+\mathrm{S} \rightarrow \mathrm{CSH} \\
& \mathrm{CH}+\mathrm{S}+\mathrm{A} \rightarrow \mathrm{C}_{2} \mathrm{ASH}_{8}
\end{aligned}
$$

Jako kolejny zamiennik spoiwa wapiennego, w zmiennej ilości (10 \%, $15 \%$, $20 \%)$ zastosowano inne spoiwo powietrzne - gips budowlany. Gips półwodny $\left(\mathrm{CaSO}_{4} * 1 / 2 \mathrm{H}_{2} \mathrm{O}\right)$ jest to wyprażona $\mathrm{w}$ temperaturze $150^{\circ} \mathrm{C}-190^{\circ} \mathrm{C}$, zmielona na proszek skała gipsowa. Jego zaletą jest szybki początek czasu (min. 5 minut) i końca wiązania (max. 20 minut). Przy zachowaniu stosunku $\mathrm{W} / \mathrm{G}=0,5$, po 1 godzinie możliwa jest do osiągnięcia wytrzymałość na ściskanie min. $9 \mathrm{MPa}$.

Procesowi wiązania gipsu towarzyszy wydzielanie się ciepła, co przedstawiają rekcje (4) i (5).

$$
\begin{aligned}
& \mathrm{CaSO}_{4} \cdot 0,5 \mathrm{H}_{2} \mathrm{O}+1,5 \mathrm{H}_{2} \mathrm{O} \rightarrow \mathrm{CaSO}_{4} \cdot 2 \mathrm{H}_{2} \mathrm{O}+\mathrm{Q}_{1}(\Delta \mathrm{H}<0) \\
& \mathrm{CaSO}_{4}+2 \mathrm{H}_{2} \mathrm{O} \rightarrow \mathrm{CaSO}_{4} \cdot 2 \mathrm{H}_{2} \mathrm{O}+\mathrm{Q}_{2}(\Delta \mathrm{H}<0)
\end{aligned}
$$

By proces przygotowania spoiw gipsowych był należycie wykonany, a także w celu by mieszanka została odpowiednio zagęszczona i ułożona dodaje się opóźniacze wiązania. Dodatek taki wynosi zwykle 0,1 - 0,5 \% masy gipsu, co przesuwa początek wiązania do 2530 minut. Jako naturalne opóźniacze stosowane są koloidy np. kazeiny. Powszechnie stosowanym opóźniaczem wiązania gipsu jest kwas winowy, który zmniejsza szybkość rozpuszczania się gipsu w wodzie.

\subsection{Skład mieszanek wapiennych}

Analizie poddano dwie serie próbek spoiwa wapiennego. Pierwsza z nich zawierająca stałą ilość metakaolinitu została modyfikowana zmienną zawartością gipsu. W drugiej serii zmieniano zawartość wody w stosunku do składników. Zaczynem porównawczym była receptura pierwsza, nie zawierająca dodatku gipsu. Procentowe zawartości składników w poszczególnych mieszankach zamieszczone są w Tab. 1. i w Tab. 2.

Tabela 1. Procentowy skład projektowanych mieszanek wapiennych o zmiennej zawartości gipsu (seria I) [źródło własne]

\begin{tabular}{llllll}
\hline Lp. & Oznaczenie & Wapno [\%] & Metakaolinit [\%] & Gips [\%] & W/S \\
\hline 1 & $0 \%$ & 90 & 10 & 0 & 0,70 \\
\hline 2 & $10 \%$ & 80 & 10 & 10 & 0,70 \\
\hline 3 & $15 \%$ & 75 & 10 & 15 & 0,70 \\
\hline 4 & $20 \%$ & 70 & 10 & 20 & 0,70 \\
\hline
\end{tabular}


Tabela 2. Procentowy skład projektowanych mieszanek wapiennych o zmiennym W/S (seria II) [źródło własne]

\begin{tabular}{llllll}
\hline Lp. & Oznaczenie & Wapno [\%] & Metakaolinit [\%] & Gips [\%] & W/S \\
\hline $3 \mathrm{a}$ & $0,65 \mathrm{~W} / \mathrm{S}$ & 75 & 10 & 15 & 0,65 \\
\hline $3 \mathrm{~b}$ & $0,7 \mathrm{~W} / \mathrm{S}$ & 75 & 10 & 15 & 0,70 \\
\hline $3 \mathrm{c}$ & $0,75 \mathrm{~W} / \mathrm{S}$ & 75 & 10 & 15 & 0,75 \\
\hline
\end{tabular}

\subsection{Przygotowanie mieszanek}

Wszystkie naturalne składniki wymieszano manualnie na sucho, po czym wsypano je do odmierzonej w odpowiednich proporcjach ilości wody. Mieszano zarób przez 90 sekund od chwili, gdy całość została umieszczona w naczyniu z odmierzoną ilością wody. Mieszankę układano i dwukrotnie wibrowano, po wypełnieniu połowy a następnie całości trójdzielnej formy do beleczek, przez łączny czas 40 sekund. Zaczyny 3a-3c oraz 4 rozformowano po 4 godzinach, natomiast pozostałe dwa z 10-procentową zawartością gipsu w tym jedną tylko z 10-procentową zawartością metakaolinitu rozformowano z powodu ich późniejszego twardnienia po 2 dniach. Próbki po rozformowaniu przechowywane były w warunkach powietrzno-suchych w temperaturze $20 \pm 2^{\circ} \mathrm{C}$ i wilgotności powietrza $60 \pm 5 \%$ przez $7 \mathrm{dni}$. Pomiarów wilgotności i temperatury dokonywano za pomocą termohigrometru cyfrowego.

\subsection{Badanie wczesnej wytrzymałości na zginanie i ściskanie}

Badanie wytrzymałości na zginanie przeprowadzono metodą trójpunktowego zginania wg. schematu na Rys. 1 dla każdej receptury na 3 próbkach o wymiarach 40 x 40 x $160 \mathrm{~mm}$. Wytrzymałość na ściskanie oznaczono na połowach przełamanych w poprzednim badaniu beleczkach, zgodnie z normą PN-EN 1015-11. Niszczące testy przeprowadzono przy użyciu maszyny wytrzymałościowej CONTROLS (Rys.2), przy przyroście obciążenia głowicy równym $50 \mathrm{~N} / \mathrm{s}$. Koniec badania następował po osiągnięciu maksymalnych sił niszczących próbkę.

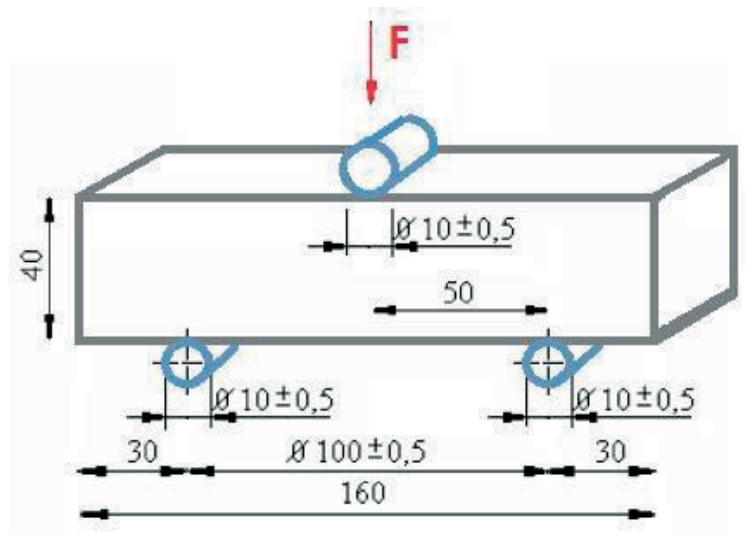

Rys. 1. Schemat rozstawu podpór w metodzie trójpunktowego zginania

Badania przeprowadzono po 7 dniach w celu określenia wczesnych właściwości wytrzymałościowych zaczynów. Próbki podczas testów niszczących przedstawione są na Rysunku 2. 


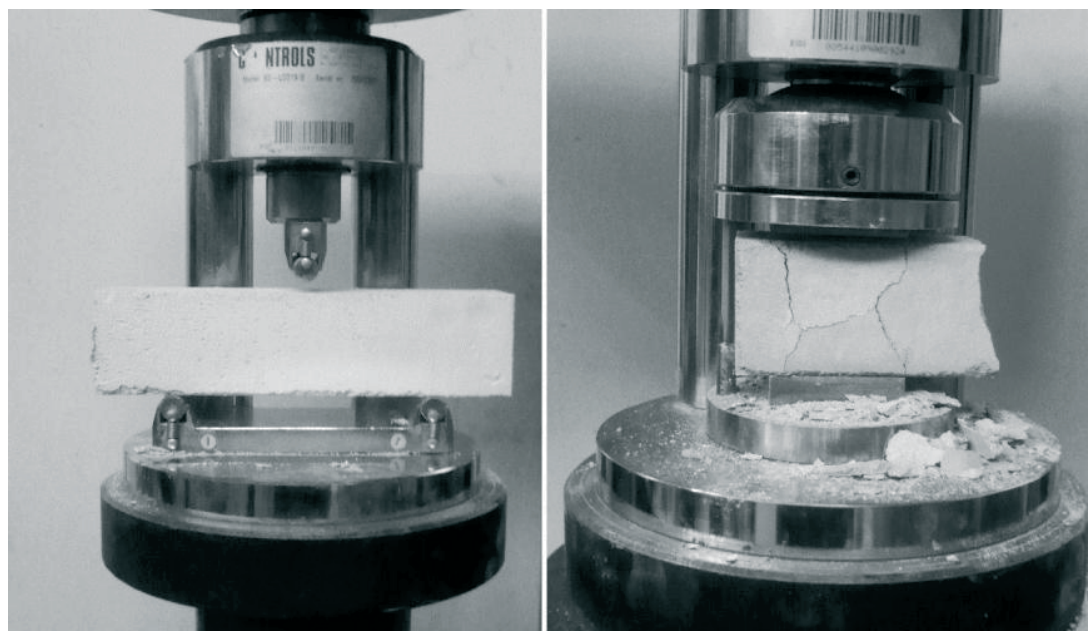

Rys. 2. Próbki wapienno gipsowe podczas badania wytrzymałości na zginanie (po lewej) i wytrzymałości na ściskanie (po prawej)

\subsection{Badanie nasiąkliwości}

Badanie nasiąkliwości przeprowadzono wg PN-EN 13755:2008 na trzech beleczkach o wymiarach $40 \times 40 \times 160 \mathrm{~mm}$, które zostały uprzednio wysuszone do stałej masy. W badaniu kontrolowany był codzienny przyrost masy próbek nasączanych wodą, aż do uzyskania stanu całkowitego nasycenia wodą. Beleczki pierwszego dnia zostały zanurzone do połowy w wodzie, natomiast w kolejnych znajdowały się już całkowicie pod wodą. Stan maksymalnego nasycenia wodą osiągnęły po 3 dniach badania.

\subsection{Badanie gęstości i porowatości}

Określenie gęstości objętościowej i porowatości wykonano zgodnie z normą PN-EN 1936:2010. W badaniu wykorzystano po trzy próbki z każdej receptury, o wymiarach 40 x 40 x $160 \mathrm{~mm}$. Beleczki o znanej objętości wysuszono do stałej masy a następnie zważono i wyliczono gęstość pozorną za pomocą wzoru (6) i gęstość właściwą, czyli stosunek masy próbki do jej objętości bez uwzględnienia porów, którą określono metodą piknometryczną na podstawie normy EN 1936:2010.

$$
\rho_{0}=\frac{m_{s}}{V_{0}}
$$

gdzie: $\rho_{0}-$ gęstość pozorna, $m_{s}$ - masa próbki w stanie suchym, $V_{0}$ - objętość próbki z uwzględnieniem porów.

Próbkę spoiwa sproszkowano do frakcji $<0,063 \mathrm{~mm}$ przy pomocy młynka kulowego. Na podstawie wyznaczonych gęstości oraz zależności (7) wyliczono porowatość całkowitą spoiwa

$$
P=\frac{\rho_{s}-\rho_{0}}{\rho_{s}} \cdot 100 \%
$$

gdzie: $P$ - porowatość całkowita, $\rho_{0}$ - gęstość pozorna, $\rho_{\mathrm{s}}-$ gęstość właściwa. 


\section{Zestawienie i analiza wyników}

\subsection{Parametry wytrzymałościowe}

Głównym celem dodatku gipsu do spoiwa wapiennego była poprawa wytrzymałości wczesnej oraz przyspieszenie czasu wiązania. Analizując otrzymane wyniki badanych właściwości mechanicznych można zauważyć kilka zależności. Ilość dodatku gipsu, a także stosunek W/S miały znaczący wpływ na wartość 7-dniowej wytrzymałości spoiw. Na Rys. 3. i Rys. 4. zobrazowano wpływ zwiększania procentowego udziału gipsu w spoiwie oraz zmianę W/S na właściwości wytrzymałościowe badanych próbek. Przedstawione wyniki są uśrednioną wartością z wyników uzyskanych dla 3 próbek. Na wykresach pokazano również słupki błędów pokazujące odchylenie od wartości średniej.
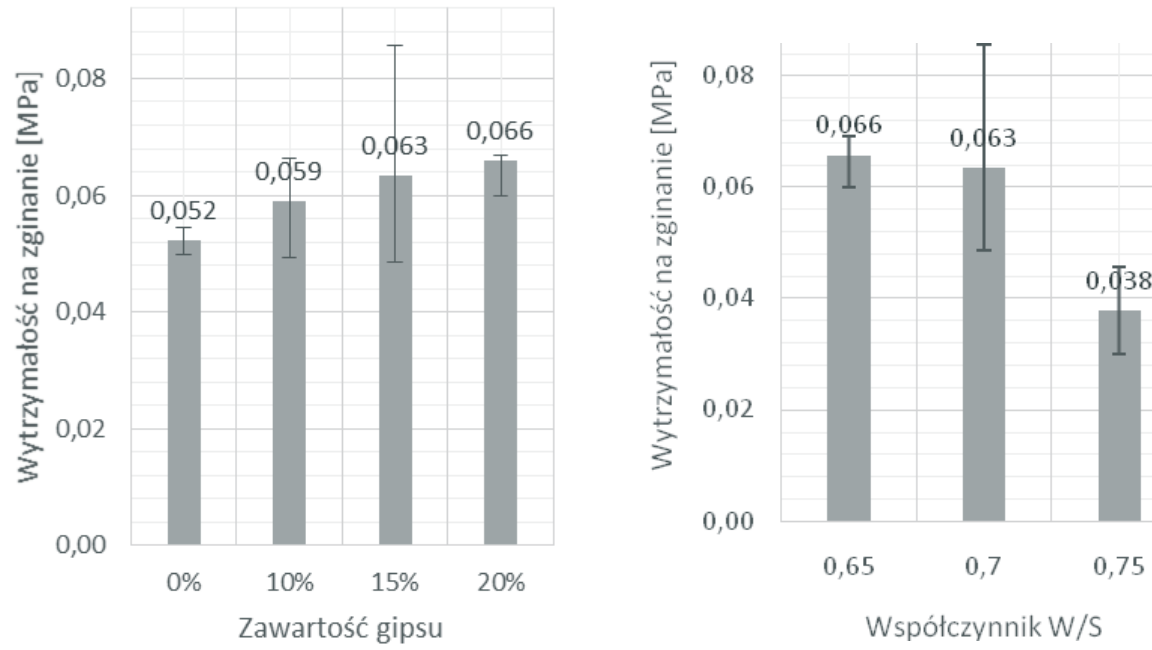

Rys. 3. Uśrednione wyniki wytrzymałości na zginanie zaczynów serii I (po lewej) i serii II (po prawej)

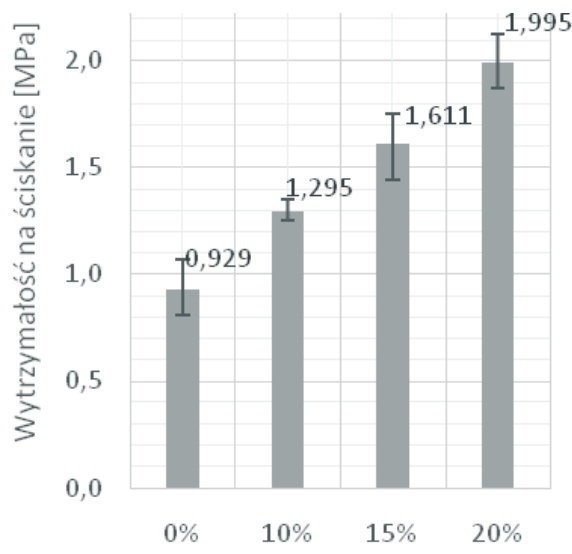

Zawartość gipsu

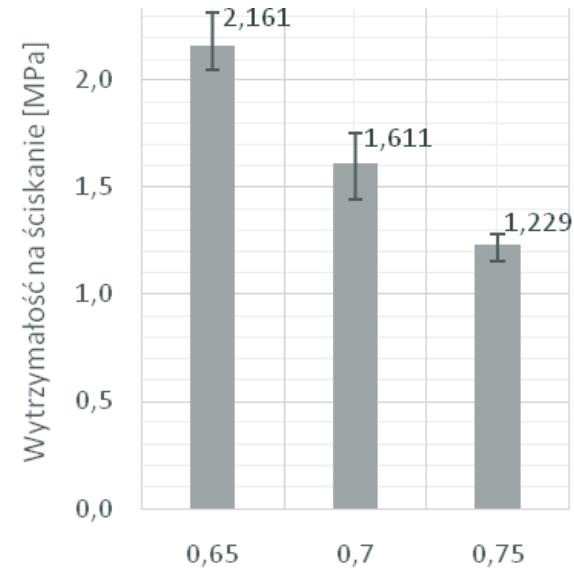

Współczynnik W/S

Rys. 4. Uśrednione wyniki wytrzymałości na ściskanie zaczynów serii I (po lewej) i serii II (po prawej) 
Zaobserwowano znaczną poprawę wczesnej wytrzymałości na ściskanie wraz ze zwiększaniem zawartości gipsu kolejno o 10\%, 15\% i 20\% w stosunku do wartości bazowej. Przy największym badanym udziale gipsu w spoiwie wytrzymałość ta wzrosła dwukrotnie w porównaniu do próbki wzorcowej bez gipsu. Zmodyfikowanie zaprawy wapiennej gipsem w ilości 10\% powodowało wzrost wytrzymałości o $40 \%$. Wzrost zawartości gipsu w kolejnych próbkach o 5\% i tym samym zmniejszenie wapna o tą samą wartość skutkowało zwiększeniem się wytrzymałości na ściskanie o ok. 24\% w stosunku do wytrzymałości próbki zwiększonej o 10\%. Zmniejszanie W/S początkowo do 0,7 , a następnie do 0,65 spowodowało wzrost wytrzymałości kolejno o $31 \%$ i $76 \%$ w stosunku do wartości dla próbki W/S 0,75.

Zwiększanie zawartości gipsu nie wpłynęło znacząco na wytrzymałość na zginanie. Można jednak zauważyć dużą niejednorodność otrzymanych wyników. Zwiększenie W/S z 0,65 do 0,75 wpłynęło za to zdecydowanie na zmniejszenie wytrzymałości o ok. 42\%.

Metakaolinit również powoduje znaczny wzrost wytrzymałości spoiwa wapiennego, jednak efekt jest widoczny bardziej po dłuższym okresie dojrzewania spoiwa lub zapraw wapiennych. Dodatek metakaolinitu w jednakowej ilości w każdej recepturze miał posłużyć jako składnik wzorcowego spoiwa (90\% wapno $+10 \%$ metakaolinit), dlatego że nie byłoby możliwości miarodajnego sprawdzenia wytrzymałości samego spoiwa wapiennego po 7 dniach, z uwagi na powolny proces twardnienia. Analiza wpływu metakaolinitu na właściwości spoiwa w badaniach własnych została pominięta, jednak na podstawie literatury [5], [6] i [7] stwierdzić można, że zwiększanie ilości tej pucolany w składzie spoiwa zwiększa jego wytrzymałość.

\subsection{Właściwości fizyczne}

Wyniki badań właściwości fizycznych: nasiąkliwości wagowej, gęstości (pozornej, właściwej) i porowatości całkowitej zestawiono w Tab. 3. i Tab. 4.

Tabela 3. Zestawienie uśrednionych wyników zbadanych właściwości fizycznych dla serii I

\begin{tabular}{llllll}
\hline Lp. & Oznaczenie & $\begin{array}{l}\text { Nasiąkliwość } \\
{[\%]}\end{array}$ & $\begin{array}{l}\text { Gęstość pozorna } \\
{\left[\mathrm{g} / \mathrm{cm}^{3}\right]}\end{array}$ & $\begin{array}{l}\text { Gęstość właściwa } \\
{\left[\mathrm{g} / \mathrm{cm}^{3}\right]}\end{array}$ & $\begin{array}{l}\text { Porowatość } \\
\text { całkowita } \\
{[\%]}\end{array}$ \\
\hline 1 & $0 \%$ & 34,29 & 1,04 & 2,49 & 58,24 \\
\hline 2 & $10 \%$ & 33,60 & 1,00 & 2,39 & 58,19 \\
\hline 3 & $15 \%$ & 33,37 & 1,00 & 2,39 & 58,16 \\
\hline 4 & $20 \%$ & 32,88 & 1,00 & 2,39 & 58,24 \\
\hline
\end{tabular}

Tabela 4. Zestawienie uśrednionych wyników zbadanych właściwości fizycznych dla serii II

\begin{tabular}{llllll}
\hline Lp. & Oznaczenie & $\begin{array}{l}\text { Nasiąkliwość } \\
{[\%]}\end{array}$ & $\begin{array}{l}\text { Gęstość pozorna } \\
{\left[\mathrm{g} / \mathrm{cm}^{3}\right]}\end{array}$ & $\begin{array}{l}\text { Gęstość właściwa } \\
{\left[\mathrm{g} / \mathrm{cm}^{3}\right]}\end{array}$ & $\begin{array}{l}\text { Porowatość } \\
\text { całkowita } \\
{[\%]}\end{array}$ \\
\hline $3 \mathrm{a}$ & $0,65 \mathrm{~W} / \mathrm{S}$ & 32,15 & 1,02 & 2,39 & 57,33 \\
\hline $3 \mathrm{~b}$ & $0,70 \mathrm{~W} / \mathrm{S}$ & 33,37 & 1,00 & 2,39 & 58,16 \\
\hline $3 \mathrm{c}$ & $0,75 \mathrm{~W} / \mathrm{S}$ & 35,45 & 0,96 & 2,33 & 58,81 \\
\hline
\end{tabular}

Gęstość spoiw wapienno-gipsowych, zarówno właściwa jak i pozorna nie zmieniała się w sposób znaczący, niezależnie od ilości zawartego w nich gipsu. Różnicę rzędu 4\% widać przy porównaniu zaczynów z gipsem i bez niego. Odnotowano również spadek 
gęstości przy wzroście wskaźnika W/S. Miało to związek z obecnością większej ilości porów, powstałych na skutek odparowania nadmiaru wody zarobowej.

Uśrednione wyniki badania nasiąkliwości oraz porównane z nimi wyniki porowatości zestawiono dla obu serii na Rys. 5.

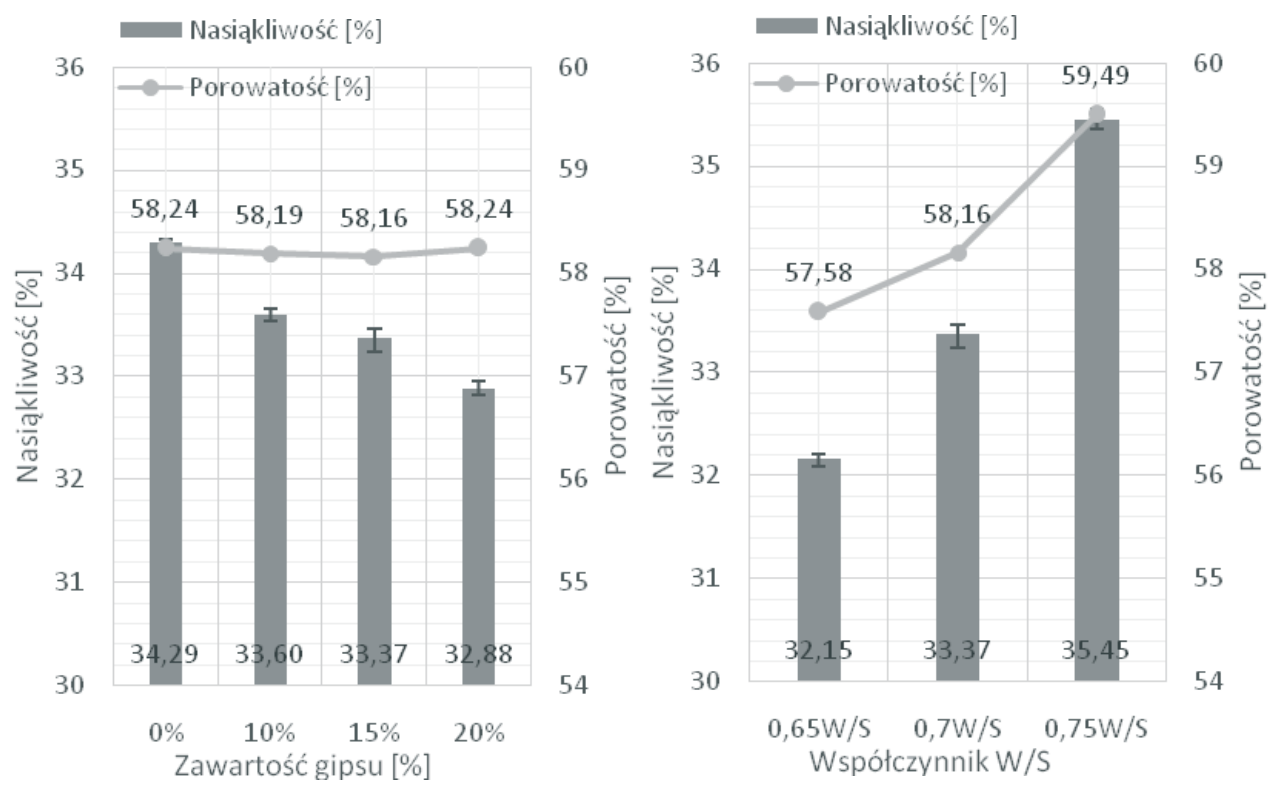

Rys. 5. Uśrednione wyniki badania nasiąkliwości i porowatości zaczynów serii i (po lewej) I serii II (po prawej)

W serii I największą nasiąkliwość osiągnęło spoiwo wapienne zmodyfikowane tylko 10-procentową zawartością metakaolinitu. Próbka z zaczynem gipsowym o wartości 10\% charakteryzowała się nasiąkliwością tylko o $2 \%$ mniejszą od próbki bez dodatku gipsu. Zwiększając zawartość gipsu o 5\% odnotowywano spadek nasiąkliwości o ok 1\% w kolejno badanych próbkach. W serii II zwiększanie wskaźnika W/S spowodowało wzrost nasiąkliwości o $4 \%$ i $10 \% \mathrm{w}$ stosunku do próbki $0,65 \mathrm{~W} / \mathrm{S}$. Zarówno spoiwo wapienne jak i gipsowe nie jest przeznaczone do zastosowań, które wymagałyby częstego lub nadmiernego kontaktu z wodą. Wapno hydratyzowane jako spoiwo do tynków ścian zewnętrznych zwiększa swą odporność na czynniki zewnętrzne poprzez długotrwały proces karbonatyzacji. Spotyka się również modyfikacje wapna, np. kazeiną - wg badań [8], zwiększając w ten sposób trwałość tynku.

Porowatość, która została wyliczona na podstawie gęstości właściwej i pozornej, w serii I nie różniła się między kolejno badanymi próbkami. Dodatek gipsu nie wpłynął na zmiany porowatości całkowitej materiału, zatem zauważalny spadek nasiąkliwości nie jest spowodowany porowatością. Z analizy Rys. 4. wynika, że próbki zawierające większą ilość gipsu są bardziej odporne na działania czynników zewnętrznych z uwagi na stopień związania spoiwa. Zwiększenie wskaźnika W/S spowodowało zwiększenie porowatości, co w konsekwencji doprowadziło do zwiększenia nasiąkliwości. W analizowanym przypadku zwiększanie o 5\% ilości wody zwiększa porowatość nieco ponad 1\%. Zbadane zaczyny charakteryzują się dużą porowatością z uwagi na konieczność wprowadzenia znaczenie 
większej ilości wody zarobowej, celem uzyskania założonej konsystencji, niż tej potrzebnej do związania spoiw. W miejscu odparowanego nadmiaru wody, powstaje sieć porów.

\section{Wnioski}

Modyfikacja spoiwa wapiennego gipsem przyspiesza czas wiązania, podwyższa wczesną wytrzymałość na ściskanie i obniża nasiąkliwość proporcjonalnie do zwiększania jego ilości. Zmniejszenie o 5\% ilości wody w stosunku do masy spoiwa korzystniej wpływa na właściwości wytrzymałościowe i nasiąkliwość niż zwiększenie o tę samą wartość ilości gipsu w spoiwie wapiennym przy stałym wskaźniku W/S. Szybkowiążącym spoiwem gipsowym można polepszać wczesne parametry wytrzymałościowe spoiwa wapiennego jeśli są one pożądane w określonym zastosowaniu w budownictwie. Wysoka porowatość całkowita blisko 60\% wpływa korzystnie na zmniejszenie gęstości spoiwa, a także zapraw. W innych przypadkach cecha ta może również przyczynić się do poprawy parametrów izolacyjności termicznej materiałów na bazie przebadanego spoiwa, jednak należałoby przeprowadzić stosowne w tym celu testy. W dalszych badaniach planuje się przebadanie kompozytów na bazie danego spoiwa, docelowo jako materiałów ciepłochronnych. Wpływ metakaolinitu na właściwości spoiwa w niniejszych badaniach nie został sprawdzony, jednak zauważalnie wpływa on na parametry mechaniczne materiału, czego dowodem była wystarczająca twardość umożliwiająca rozformowanie próbki wzorcowej (90 \% wapno + $10 \%$ metakaolinit) po 2 dniach.

Dodatek gipsu do spoiwa wapiennego zwiększa jego wczesną wytrzymałość na ściskanie i zginanie, dzięki czemu można przyspieszyć wykonanie kolejnych etapów prac budowlanych.

\section{Literatura}

1. Osiecka E. Wapno w budownictwie - tradycja i nowoczesność. Stowarzyszenie Przemysłu Wapienniczego, Kraków (2006).

2. Czarnecki L., Łukowski P. Spoiwa wapienne - historia, stan obecny i perspektywy. Materiały Budowlane 10 (2008) 3-7.

3. Auberta J. E., Seguia P., Hussona B., Measson M. A method developed to quantify lime and gypsum consumed by mineral additions. Cement and Concrete Composites, August 34(7) (2012) 874-880.

4. Vimmrová A., Keppert M., Michalko O., Černý R. Calcined gypsum-lime-metakaolin binders: Design of optimal composition. Cement and Concrete Composites, September 52 (2014) 9196.

5. Tesarek P., Tydlitat V., Drchalova J., P. Rownanikowa P., Cerny R. Właściwości zaprawy wapiennej z dodatkiem metakaolinitu. Cement Wapno Beton, 4 (2005).

6. Gameiro A., Santos Silva A., Faria P., Grilo J., Branco T., Veiga R., Velosa A. Physical and chemicalassessment of lime-metakaolin mortars: Influence of binder: aggregate ratio. Cement and Concrete Composites 45 (2014) 264-271.

7. Łukowski P. Możliwości modyfikacji spoiwa wapiennego domieszkami i dodatkami. Materiały Budowlane 10 (2010) 31-32,41.

8. Ventolà L., Vendrell M.,, Giraldez P., Merino L. Traditional organic additives improve lime mortars: New old materials for restoration and building natural stone fabrics. Construction and Building Materials 25 (2011) 3313-3318. 


\title{
Modified lime binder with gypsum and metakaolin
}

\author{
Przemysław Brzyski, Katarzyna Świderczuk
}

Department of Construction, Faculty of Civil Engineering and Architecture, Lublin University of Technologye-mail: p.brzyski@pollub.pl, katarzyna.swiderczuk@wp.pl

\begin{abstract}
Lime is used as a building material for thousands of years. Nowadays, due to its low mechanical strength and low resistance to weather conditions it is reduced or even discontinued its use in the construction industry. This natural building material has a positive effect on the microclimate inside buildings, and through alkaline nature, prevents the formation of mold. The use of lime as a replacement for traditional materials, like cement will bring not only environmental but also economic benefits.

This paper describes the own study of basic physical and mechanical properties of modified lime binder. In order to improve the unfavorable performance of lime binder it was modified by variable quantity of gypsum in an amount of $10 \%, 15 \%, 20 \%$ by mass, and different water content by ratio water/binder $0.65,0.7,0.75$ for a mixture which contains $15 \%$ of gypsum. In all formulations a constant amount of metakaolinite equal to $10 \%$ by weight of the binder was used. In the studies, after 7 days of maturation, a flexural and compressive strength test were performed. Also the density, porosity and water absorption of binder were examined. With an increase in the content of gypsum was an increase of strength parameters and a decrease in water absorption with minor changes in porosity. Much bigger differences were observed after the modification of water/binder ratio - with its decline the strength increased and the water absorption and porosity decreased.
\end{abstract}

Keywords: lime, gypsum, metakaolin, strength, absorptivity, density, porosity. 